\title{
Characteristics of meatness traits in six generations of ducks in conservative groups*
}

\author{
J. Książkiewicz \\ Department of Waterfow/ Breeding. Dworzyska \\ Poultry Research Center \\ 62-022 Swiainiki n. Warta, Poland
}

(Received 15 July 1996; accepted 6 February 1997)

\begin{abstract}
In 6 generations of ducks from 4 conservative groups: Khaki Campbell (Kh1), Orpington (01), their crosses $(\mathrm{KhOl})$ and Miniducks $(\mathrm{K} 2)$, mean values of some meatness traits, their coefficients of variation $\left(v, v_{\text {years }}\right)$ and repeatability $\left(r_{p}\right)$ were estimated. Live weight of the 7-week-old birds and contents of the investigated tissuc components in the carcass differcd depending on the origin and sex of the birds. In all groups, lower $v$ and $v_{\text {years }}$ values of live weights in the $3 \mathrm{rd}$ and 7 th week of life were found in females, while the $r_{p}$ values were higher than those in males. High values of $v$ (up to $22 \%$ ) and of $v_{\text {years }}$ (up to $26 \%$ ) were found in 3-week-old drakes in live weight of 3-week-old drakes and in breast muscless content in the carcasses of 7 -week-old males (up to 17 and $21 \%$, respectively).

High $r_{p}$ values were found concerning the live weight of 7 -week-old ducks $(0.4-0.8)$, middlde $r_{p}$ values concerning the live weight in 7-week-old drakes as well as those of per cent contents of breast and leg muscles in the carcasses of drakes and ducks (0.1-0.6), while they were low in 3-week-old birds and in the carcass contents of skin with subcutaneous fat in birds of both sexes (0.1-0.3). The highest live weight at the age of 7 weeks was noted in Orpingtons, but the highest content of breast muscles was found in Miniduck carcasses.
\end{abstract}

KEY WORDS: ducks, conservative group, live weight, tissue composition, variation, repeatability

\section{INTRODUCTION}

Conservation of domestic animal diversity (DAD), including birds, is necessary not only from the breeding and scientific, but also from the economic

* Carried out under the PRC, Z-16/94 project 
as well as biological, cultural and historical points of view (Simon, 1984; Wężyk, 1984; Yang and Wu, 1988; Baumgartner et al., 1992; Crawford, 1993).

Conservative groups of ducks have been maintained since 1977 by an in situ method (Książkiewicz, 1984) as a source of genetic variation at the Department of Waterfowl Breeding at Dworzyska (Poznan region). They were used to form new breeding and experimental strains, synthetic groups as well as for searching for heterosis in commercial sets (Książkiewicz, 1995). This type of research requires ongoing observation of performance in birds in the conservative groups (Książkiewicz, 1984, 1995). This evaluation had been continued over many generations in comparable environmental and feeding conditions, and using the same methods, what permits characterization of the individual conservative groups as to their performance.

The aim of the presented investigations was to determine the live weight of 3- and 7-week old birds and the contents of some tissue components in their eviscerated carcasses, to evaluate the groups basing on their performance in 6 generations, as well as to calculate the coefficients of variation and repeatability of the investigated traits.

\section{MATERIAL AND METHODS}

The object of the investigations was the ducks' progeny in 4 conservative groups, used for reproduction every other year between 1983-1993 in 6 consecutive generations (the interval between generations beeing two years). The Khaki Campbells (Khl) were imported from Jansen (France) in 1978, Orpingtons (O1) were bought in France in 1971, crosses of these breeds issued from two way crossing (KhO) and Miniducks (K2) combined with Mallard (Anas platyrhynchos L.) and Pekin genotypes (Książkiewicz, 1982).

These groups were subjected to a program of natural preservation in the condition used in maintaining waterfowl genetic reserve (Mazanowski, 1984). Namely, among others, no selection for productive traits has been applied. The parent groups were randomly completed for copulation and reproduction every second year.

The birds of each group were kept in 4 subgroups what makes it possible to avoid inbreeding by rotating the males in the subgroups. In each group, 50 to 200 birds of each sex were evaluated in every generation. The numbers of drakes and ducks in 6 generations evaluated individually in each group are presented in Table 1. Together, in 6 generations, 2302 3-week-old drakes and 2903 ducks of the same age, and 2224 drakes and 2829 ducks 7 -week-old were weighed. From each group five males and five females of live weight close to the arithmetical mean of the group's mean live weight were chosen for dissection analyses. 
Feeding and management of the birds in consecutive years were similar and in accordance with generally used principles of rearing ducks. During the first 3 weeks of life they were kept inside buildings with regulated environmental conditions and later on they stayed in the runs of a limited area, partly under a roof and on straw litter.

In each generation the birds were fed ad libitum on complete feeds of similar chemical composition. Their diet up to the $3 \mathrm{rd}$ week of life contained 19-20\% crude protein and 2850-2900 Kcal metabolizable energy (1 1.92-12.13 MJ). Then to the 7 th week the birds received $16-16.5 \%$ crude protein and $2950 \mathrm{Kcal}$ (12.34 MJ) metabolizable energy. The mashes were of commercial origin and their composition of raw material slightly changed.

In all successive generations the numerical data concerning live weight and per cent contents of breast, thigh and drumstick muscles and skin with subcutaneous fat in carcass were statistically charactcrized by variance analysis and calculation of the significance of differences. The method of variance analysis in a random model was used for estimating variance in years, separately in each group. Then the coefficient of variation of years $\left(v_{\text {years }}\right)$ was calculated by dividing the square root of variance of years in the analyzed group by the mean value of the trait in this group $\mathrm{x} 100 \%$. By application of variance analysis in the random model, the estimation of the year's variance in each group separately was calculated as well as the coefficients of repeatability $\left(r_{p}\right)$ between years in each groups.

\section{RESULTS}

Table 1 shows that the live weight of birds differed depending on their origin, sex and age. Live weights in the 3rd week of life were similar (522-600 g) but most groups differed significantly. No statistically significant differences were found between the drakes from groups $\mathrm{Kh} 1$ and $\mathrm{O} 1$ as well as between $\mathrm{KhO}$ and $\mathrm{K} 2$. In the 7 th week the drakes had a higher live weight than the ducks, in contrast to the situation at 3 weeks of age. The heaviest were $\mathrm{O} 1$ group birds of both sexes, while the lightest were $\mathrm{Kh} 1$ and $\mathrm{K} 2$, the differences with other groups were statistically significant.

For the live weight of 7-week-old birds, v values were lower $(8.7-11.2 \%)$ than those in 3-week-old ones (16.1-22\%). The coefficients of variation calculated between years were lower in both sexes of 7-week-old birds $(2.9-9.8 \%)$, while in the 3-week-old ducks they were 7.6-17.7\%. The coefficients of live weight repeatability were the highest in 7-week-old ducks $(0.4-0.8)$, lower in 7-week-old drakes (0.1-0.6) and the lowest in 3-week-old birds of both sexes (0.11-0.3).

The conservative groups differed between each other in the percentage of muscles and skin with subcutaneous fat in their carcasses (Table 2). The highest 
KSIĄŻKIEWICZ J.

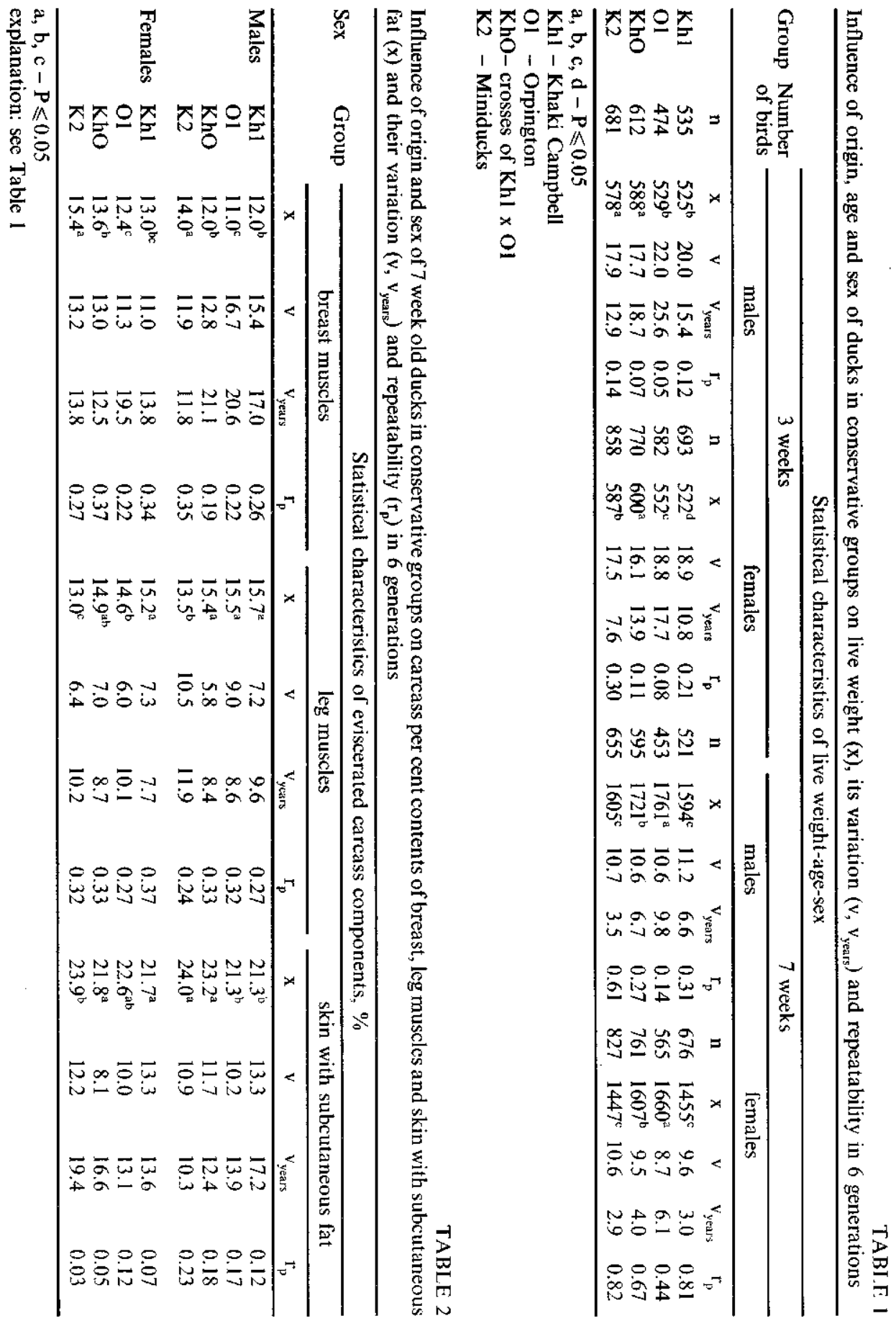


contents of breast muscles (14\% in drakes and $15.4 \%$ in ducks) and the lowest content of leg muscles ( 13.5 and $13 \%$, respectively) in the carcass were found in Miniducks, and the differences in relation to other groups were statistically significant. The eviscerated carcasses of these birds $(\mathrm{K} 2)$ contained $24 \%$ skin with subcutaneous fat. The differences in this trait of $\mathrm{KhO}$ males and $\mathrm{Ol}$ females were not statistically significant.

The lowest percentages of breast muscles were found in $\mathrm{O} 1$ males and females, while the highest per cent content of leg muscles was found in the carcasses of $\mathrm{Kh} 1 \mathrm{birds}$. High variation was observed in breast muscles content, the coefficient of variation ranging from 11 to $16.7 \%$. It was lower in the case of skin with subcutaneous fat $(v=8.1-13.3 \%)$ and the lowest in leg muscles content $(\mathrm{v}=5.8-10.5 \%)$. The variation between years concerning breast muscles $(11.8-21.1 \%)$, skin with subcutaneous fat $(10.3-19.4 \%)$ and leg muscles $(8.4-11.9 \%)$ contents was higher. The highest repeatability was found in breast and leg muscles contents $(0.19-0.37)$, while that concerning skin with subcutaneous fat was lower $(0.03-0.23)$.

\section{DISCUSSION}

The ducks of the investigated groups were characterized by approximate values of meatness traits and compared with those of ducks evaluated in previous studies at the ages of 8 (Książkiewicz, 1984) and 7 weeks (Książkiewicz and Kontecka, 1993).

Good repeatability of this traits was the result of high heritability of the tested traits (Staško, 1990) and comparable conditions of environment and feeding. The presented study confirmed the earlier observations (Książkiewicz, 1984) of lower live weight of $\mathrm{Khl}$ and $\mathrm{K} 2$ than of $\mathrm{O} 1$ and $\mathrm{KhO}$ ducks, the highest per cent contents of breast muscles of $\mathrm{K} 2$, thigh and drumstick muscles of Kh1 birds. The ducks of the conservative groups had lower live weight at 3 and 7 weeks of age and had less fat (Rizk, 1975) than the Pekin type birds.

Other authors who estimated live weight, and breast and leg muscles contents, as well as skin with subcutaneous fat of different duck types, also noticed considerable differentiation of the tested traits (Hudský and Cerveny, 1973; Rizk, 1975; Hetzel and Simmons 1983; Staško, 1990).

Mean live weight of 7-week-old Khaki Campbell ducks was similar to that observed in this breed in other environmental and feeding conditions (Hudský et al., 1973; Hetzel and Simmons, 1986). The ducks of this breed were used for crossing with indigenous varieties in Indochina, China and India in order to obtain crosses laying more eggs for consumption or to improve other productive traits (Yang and $\mathrm{Wu}, 1988$ ). They were also used for creation of new strains as 
Minikos and Pekinos (Rizk, 1973; Staško, 1990). Orpington ducks of a dual-purpose type are rarely encountered in Europe. In the presented study their live weight appeared to be lower than reported by Baumgartner et al. (1992). The evaluation of Miniducks' meatness confirmed the opinion of Staško (1990) that the carcasses of hybrids resulting from crossing with Mallard distinguished by good musculature and higher per cent content of breast muscles than that in Pekin ducks.

High variation of live weight in the 3 rd week of life and of percentages of breast muscles in the carcasses of 7-week-old ducks have been often noticed (Książkiewicz, 1982, 1984; Książkiewicz and Kontecka, 1993). The coefficients of variation of other traits did not differ from values found in previous investigations carried out on the conservative groups, which would point to the continuation of this variability in the tested traits. In the available references there were no data concerning analysis of variation and repeatability of the traits in many generations of unselected duck populations.

The rather high values of variation coefficients in the tested traits confirm that in the maintaining of the conservative groups the proper method was used. In the time of investigations on consecutive generations there was no change in variation of the traits.

\section{CONCLUSIONS}

Differentiation in live weight and in the contents of some tissue components in the carcass was found in duck breeds: Khaki Campbell, Orpington, their crosses and Miniducks. In all groups the ducks had lower $v$ and $v_{\text {years }}$ values of live weight at 3 and 7 weeks of age, but higher $r_{p}$ values than those in the drakes.

High $v$ and $v_{\text {year }}$ values were found in live weight of 3-week-old drakes (up to 22 and $26 \%$, respectively) and in the contents of breast muscles in 7-week-old drakes (up to 17 and $21 \%$ ).

High $r_{p}$ values were found in live weight of 7 -week-old ducks $(0.4-0.8)$, mean in live weight of 7 -week-old drakes and in the contents of muscles of in the breast and legs in the carcasses of both sexes $(0.1-0.6)$, but they were low in the live weight of 3-week-old drakes and ducks, as well as in the carcass content of skin with subcutaneous fat in birds of both sexes $(0.1-0.3)$. The high variation in these traits indicates that the proper method of management was used in maintaining the conservative groups. 


\section{REFERENCES}

Baumgartner J., Miček L., Ledeč M., Benkov J., Soukupová Z., 1992. Uchovávanic a využitie génových rezerv v chove hydiny. Akad. Zémédel Véd Sb. 159, 53-69

Crawford R.D., 1993. Gene resources: global view of jnventory and conservation. In: Proceedings of 10th International Symposium on Current Problems of Avian Genetics, Nitra, pp. 131-136

Hetzel D.J.S., Simmons G.S., 1983. Growth and carcass characteristics of Alabio, Bali, Tegal and Khaki Campbell drakes on a high plane of nutrition. Sabrao J. 15 (2), 117-123

Hudský Z., Červeny J., 1983. Analysis of meat type ducks (in Czech). Živ. Výroba 28, 235-240

Hudský Z., Lautner V., Blažek J., 1973. Carcass characteristics of different types of ducks (in Czech). Živ. Výroba $18,65-70$

Książkiewicz J., 1982. Performance of small meat ducks (in Polish). Wyniki Badań Nauk., COBRD Poznań 1, 45-65

Książkiewicz J., 1984. Meat traits of ducks of conservative groups (in Polish). Roc $z$. Nauk. Zoot. 11 (2), 49-61

Ksiązkiewic J., 1995. Duck gene pool. In: Proceedings of International Symposium on Conservation Measures for Rare Farm Animal Breeds, Balice (Poland), pp. 289-292

Książkiewicz J., Kontecka H.,1993. ^ characteristics of dependence between body weight, body measurements and carcass tissue composition of Miniduck, Orpington and ducks with different content of Khaki Campbell (in Polish). Rocz. AR Poznan, 246, Zoot. N ${ }^{\mathrm{v}} 44,45-56$

Mazanowski A., 1984. Methods of waterfowl gene preservation (in Polish). Biul. inf. Inst. Zoot. 22 (3), 14-23

Rizk M.A., 1975. Vergleichende Untersuchungen über Mast- und Ausschlachtungsleistungen sowic Fleisch-Qualitätsmerkmale bei Verschiedenen Geflügel-Arten und -Herkünften. PhD. Thesis, University Bonn

Simmon D.L., 1984. Conservation of animal genetic resources - a review. I ivest. Prod. Sci. 11, 23-26 Staško J., 1990. Variation in parameters at the duck breeding. In: Proceedings of 8th European Poultry Conference, Barcelona, pp. 497-500

Węzyk S., 1984. Methods of conserving poultry gene reserves (in Polish). Biul inf. Inst. Zoot. 22 (4-5), 79.98

Yang C., Wu K., 1988. Breed resources and conservation measures in Chinese indigenous waterfowl. In: Proceedings of 18 th Poultry Congress, International Symposium on Waterfowl Production, Beijing (China), pp. 113-118

\section{STRESZCZENIE}

\section{Charakterystyka cech mięsnych sześciu pokoleń kaczek $\mathrm{z}$ grup zachowawczych}

W sześciu pokoleniach z grup zachowawczych kaczek Khaki Campbell, Orpington, mieszańców tych ras i Mini-kaczek oszacowano średnią wartość wybranych cech mięsnych, ich wspólčynniki zmienności $\left(\mathrm{v}, \mathrm{v}_{\text {lat }}\right)$ i powtarzalności $\left(\mathrm{r}_{\mathrm{p}}\right)$. Masa ciała $\mathrm{w} 7$. tygodniu zycia i zawartość w tuszce badanych składników tkankowych różnila się w zależności od pochodzenia i płci ptaków. Najcięższe byly Orpinglony (1761 g $\bar{\zeta}$ i $1660 \mathrm{~g} \mathrm{O}$ ), najlżejsze Khaki Campbell i Mini-kaczki (po około $1600 \mathrm{~g}$ \% i $1450 \mathrm{~g}$ ). 
We wszystkich grupach kaczki charakteryzowały mniejsze wartości v i $v_{\text {lat }}$ masy ciała w 3. i 7 . tygodniu życia $i$ większe wartości $r_{p}$ tych cech niż kaczorów. Wysokie wartości v $\left(\right.$ do $22 \%$ ) i $v_{\text {lat }}$ (do $26 \%$ ) stwierdzono u 3-tygodniowych kaczorów pod względem masy ciała oraz zawartości mięśni piersiowych w tuszkach 7-tygodniowych kaczorów (odpowiednio do 17 i $21 \%$ ).

Wysokie wartości $r_{p}$ oszacowano pod względem masy ciała 7-tygodniowych kaczek (od 0,4 do 0,8 ), średnie dla masy ciała 7-tygodniowych kaczorów oraz procentowej zawartości mięśni piersiowych i nóg w tuszkach kaczorów i kaczek (od 0,1 do 0,6 ), a niskie dla masy ciała 3-tygodniowych ptaków oraz dla zawartości w tuszce skóry z tłuszczem podskórnym u ptaków obojga płci (od 0,1 do 0,3). Największa mase ciała w 7. tygodniu życia miały Orpingtony, a największą zawartość mięśni piersiowych w tuszce Mini-kaczki. 